\title{
Environmental impact of trawling on the seabed: a review
}

\section{J. B. JONES}

Fisheries Research Centre

Ministry of Agriculture and Fisheries

P. O. Box 297

Wellington, New Zealand

Abstract Fishers have been complaining about the effects of bottom trawl gear on the marine environment since at least the 14th century. Trawl gear affects the environment in both direct and indirect ways. Direct effects include scraping and ploughing of the substrate, sediment resuspension, destruction of benthos, and dumping of processing waste. Indirect effects include post-fishing mortality and long-term trawl-induced changes to the benthos. There are few conclusive studies linking trawling to observed environmental changes since it is difficult to isolate the cause. However, permanent faunal changes brought about by trawling have been recorded. Research has established that the degree of environmental perturbation from bottom trawling activities is related to the weight of the gear on the seabed, the towing speed, the nature of the bottom sediments, and the strength of the tides and currents. The greater the frequency of gear impact on an area, the greater the likelihood of permanent change. In deeper water where the fauna is less adapted to changes in sediment regimes and disturbance from storm events, the effects of gear take longer to disappear. Studies indicate that in deep water $(>1000 \mathrm{~m})$, the recovery time is probably measured in decades.

Keywords New Zealand; trawling; environment; damage; impact; effects; benthos; sediment; mortality

M91040

Received 23 July 1991; accepted 9 January 1992

\section{INTRODUCTION}

There is growing public and political awareness of the environmental impact of fishing activities. This is reflected in the U.N. Convention for the Conservation of Antarctic Marine Living Resources (CCAMLR) which requires (Article II) that signatory States harvest resources in such a way that the direct and indirect effects on the marine ecosystem are minimised, and that changes which are not potentially reversible over 2 or 3 decades are prevented.

The long-established technique of bottom trawling is attracting increasing criticism over the perceived environmental damage it may cause. This is of particular concern in Australasia where commercial fishers are developing new trawling grounds down to $1200 \mathrm{~m}$ (Judd 1989) and will certainly fish deeper as technology improves. Whether bottom trawling causes environmental damage which is not potentially reversible over a few decades is the subject of this paper. For the purposes of this review, bottom trawling includes the use of beam trawls, dredges, otter trawls, and Danish seine-nets, but not hydraulic clam dredges. A review of the effects of the latter can be found in Meyer et al. (1981).

\section{Historical overview}

As early as 1376 the British Parliament was petitioned by fishers concerned over the damage done to their fisheries by bottom trawling. Early complaints included the capture of undersize fish, the indiscriminate capture of non-target species, and a perception that fishing was deteriorating. Trawling also destroyed "the living slym and underwater plants" (March 1970; De Groot 1984). Gear used by sailing beam trawlers was relatively light and was towed at slow speed in shallow water. It was not until the advent of the steam trawler in the 1900s that the size and weight of the trawl gear began to increase, in particular through the use of "tickler" chains (chains between the wings of the trawl scraping the seabed ahead of the footrope). Following complaints from fishers, one of the earliest studies on the effects of such gear was carried out during 1938 on the plaice 
fishing grounds in the North Sea (Graham 1955). From that study, based on comparisons of catches from normally fished grounds and from areas where commercial trawlers did not usually fish, Graham (1955) concluded that trawling was having no longterm effect on the macrobenthos.

By the end of World War II, the use of the powered trawler towing an "otter" or "Granton" trawl had become widespread. However, the beam trawl had also persevered, with the introduction of heavy tickler chains and chain chaffing mats. The weight of these beam trawls increased steadily with the increasing power of the towing vessel. Beam trawls weighed up to $3.5 \mathrm{t}$ total weight in the late $1960 \mathrm{~s}$ (Cole 1971) but by the early 1980 s had reached about $10 \mathrm{t}$ (Beek et al. 1990). The heavy tickler chains were known to dig up and displace large boulders which then damaged the lighter gear of other fishers. The chains made the gear more efficient at catching demersal fish and crustaceans (Anon. 1971; Chittenden \& van Engel 1972; Harden Jones \& Scholes 1974) and their use persisted despite complaints by other fishers (Anon. 1971).

In the early 1970 s, the French "Institut Scientifique et Technique des Pêches Maritimes", concerned at the changes to the bottom topography of fishing grounds around Corsica - which they attributed to heavy chain on trawls - obtained a ban on the use of this gear in the Mediterranean (De Groot 1984). They then sought a similar ban on Dutch beam trawlers working along the French Atlantic coast. Fisheries laboratories bordering the North Sea had not noticed any significant changes to the benthos over time, and other countries were even less convinced that a problem existed (Anon. 1971; Cole 1971). The subject was raised at the 58th International Council for the Exploration of the Sea (ICES) meeting in 1970 and resulted in an ongoing series of studies on the effects to the benthos of all trawl gear types. Most of these studies are unpublished ICES working papers and are referenced in Redant (1987, 1990). A 1988 ICES study group concluded that changes in the benthic community could be related to fishing. However, no firm conclusions could be reached because relevant information on the physical effects of trawling was not available, and the impact of other effects such as eutrophication and pollution could not be estimated. In 1990, ICES established a working group to evaluate the effects of fishing on the marine ecosystem, including the effects on marine mammals, birds, and benthos (Rijnsdorp et al. 1991).

Early studies (generally in shallow water and on sand or mud) showed that benthic organisms were exposed to predators by the action of trawl gear (e.g., Amtz \& Weber 1970; Caddy 1973), but it was concluded that this extra food source could only benefit the fishery. If there was a reduction in the invertebrate fauna, it was felt that this would be of no account as food availability was not usually limiting to fisheries (Cole 1971).

More recent studies have examined the effects of trawling on hard-bottom communities and assessment of the impact has varied. Following concerns that trawl gear might reduce the amount of productive fish habitat (Wenner 1983), Dolah et al. (1987) reported the results of a single research trawl tow (in $20 \mathrm{~m}$ depth) on a hard-bottom assemblage of sponges and corals. They concluded that, though damage was caused, the effects could not be detected after 12 months. This result contrasted with a 1979 study in Florida by Tilmant (cited in Dolah et al. 1987), who used a prawn trawl, and who was working in an area heavily fished by prawn trawlers.

As the concept of community ecology has become established and the realisation has grown that the associated fauna provide more than just a food source for the target fishery (Sainsbury 1988), the debate over the long-term chronic effects of observed seabed changes has continued. This debate is not confined to Europe as similar concerns over the effects of trawling have been voiced in Australia (Gibbs et al. 1980; Butcher et al. 1981; Hutchings 1990), New Zealand (Saxton 1980; Bradstock \& Gordon 1983), Indonesia and Thailand (Chong et al. 1987), and in North America (Dolah et al. 1987; Goudey \& Loverich 1987; McAllister 1991). Apollonio (1989) went as far as to question whether eliminating the otter trawl could be the key to better fisheries management. A similar view was put forward by Chong et al. (1987) following the 1980 Indonesian Government ban on trawling (trawling was primarily for prawns with pre-ban landings of 130000-200 000 t). Chong et al. (1987) reported that the trawl ban caused no reduction in the total Indonesian marine landings but there was, however, a positive impact on fishing profitability. The reasons for this were complex, involving the recovery of overfished stocks, improved value of the catch, and the distribution of wealth derived from the fishery among the local communities rather than to offshore trawling companies. In New Zealand, Fenaughty \& Bagley (1981) note that the Otago fishery was far more productive in tonnage landed in the early 1900 s than it was in the 1970s, despite the introduction of large trawlers and modern trawl gear.

Allied with trawling activities is the problem of disposing unwanted catch, fish heads, and frames. 
Dumping this waste at sea benefits predatory fish, marine mammals, and seabirds (an aspect outside the scope of this review). However, concern has been expressed at the effects on the seabed of discharging substantial quantities of such waste (Livingston \& Rutherford 1988). Trials have shown that dissolved oxygen levels could be affected near the seabed but no studies have been made on the grounds.

\section{OBSERVED EFFECTS}

Trawl gear has a direct physical effect on the seabed wherever the ground rope, chains and bobbins, sweeps, doors, and any chaffing mats or parts of the net bag contact the bottom. Ways in which gear affects the seabed can be classified as: scraping and ploughing; sediment resuspension; and physical destruction, removal, or scattering of non-target benthos. The fishing operation further affects the seabed through waste dumped from the vessel. Indirect effects on the seabed are related to the stress imposed on the benthos. These effects include post-fishing mortality of damaged or disturbed organisms, and long-term changes to the benthos community structure.

\section{Scraping and ploughing}

Otter boards imprint distinct tracks on the seafloor, ploughing a groove which can vary from a few $\mathrm{cm}$ up to $0.3 \mathrm{~m}$ deep (Amtz \& Weber 1970; Caddy \& Iles 1972; Krost et al. 1990). Bobbins and chains can also leave recognisable tracks (Krost et al. 1990) and may skim off the surface sediment layers between the two grooves left by the otter boards. The depth of the otter board groove depends on the weight of the board (which can be several tonnes), the angle of attack (the board is towed at an angle to the direction of motion to generate the lift required to spread the net), and the nature of the substrate, being deepest in soft mud.

These trawl tracks remain visible for varying times depending on the nature of the substrate and on water movements over the bottom. The greater the water movement, the faster the tracks will be filled in. Bemhard (reported in Krost et al. 1990) found that the sandy mud of Eckernforde Bay held the same trawl track for almost 5 years. Churchill (1989) and Krost et al. (1990) reported an increase in the frequency of tracks attributed to trawl doors in deeper water, presumably where water movement is less pronounced.

Appreciable areas of the fishing grounds can be affected. Caddy (1973) calculated that c. $3 \%$ of the bottom area in Chaleur Bay (Gulf of St Lawrence) was covered in what were presumed to be trawl tracks. Studies by Caddy \& Iles (1972) revealed a high frequency of trawl tracks on parts of the Georges Bank area of the Northwest Atlantic. Churchill (1989) reported up to 20 tracks $/ 100 \mathrm{~m}^{2}$ at depths of $100 \mathrm{~m}$ on the southern New England shelf.

Each set of trawl tracks defines an area swept by a trawl. Even if the footrope and net were clear of the bottom, the benthos between these tracks would still have been affected by turbulence. In a detailed survey of Kiel Bay (Baltic), Krost et al. (1990) found up to $19 \%$ of the study area, which was deeper than $20 \mathrm{~m}$ and in mud, bore trawl tracks. They calculated that there was a "more or less complete" disturbance in those areas where trawl tracks were classified as "abundant" (10-35\% of the survey area). In the Netherlands, where the spatial distribution of fishing effort is known for $30 \times 30$ mile squares, it has been calculated that, in heavily fished squares, every square metre of the seabed is trawled, on average, at least 7 times a year (Rijnsdorp et al. 1991).

\section{Sediment resuspension}

The sediment cloud generated by turbulence from trawl doors contributes to fish capture, especially in clear water (Main \& Sangster 1979, 1981). However, these trawl sediment clouds can also contribute to the total suspended sediment load. Churchill (1989) modelled sediment resuspension by trawling and found that this may be a primary source of suspended sediment over the outer shelf $(100-140 \mathrm{~m})$ where storm-related bottom stresses are weak. This suspended sediment reduces light levels on the substrate, and when the sediment eventually settles out, the benthos can be smothered. Galtsoff (1964) showed that as little as a $1 \mathrm{~mm}$ layer of silt over a settlement surface could prevent spat settlement in Ostrea virginica and Stevens (1987) claimed that high levels of turbidity inhibited settlement of Pecten novaezelandiae veliger larvae, depressed growth rates of adults, and caused inefficient metabolism of glycogen stores through enforced anaerobic respiration.

Theil \& Schriever (1990) studied sediment resuspension in deep-ocean environments. They found that an experimental plot at $4000 \mathrm{~m}$, previously ploughed repeatedly with a rig resembling a trawl bobbin gear and chains, had not recovered from the effects of sediment redeposition after 6 months. Even the harpacticoid copepod fauna remained significantly reduced (G. Schriever pers. comm.). Their assessment 
was that the substrate would take decades to recover.

As well as resuspending sediment, trawl gear can bring about vertical redistribution of sediment layers. Mayer et al. (1991) showed that heavy chain dredges could mix surface organic material into subsurface layers. This organic material was removed from the surface metazoan-microbial aerobic chain to an anaerobic system. If the subsurface layers are already anoxic, furthur problems can occur. Churning up the soft bottom can create anaerobic turbid conditions which are, for example, capable of killing scallop (Platinopecten sp.) larvae (Yamamoto 1960). The question whether the resuspended organic material improved nutrient availability to filter feeders was studied by Anderson \& Meyer (1986) who found that sediment resuspended from clam dredges in a Maine estuary did not improve the food value of the suspended material available to filter feeders, and if expressed as protein per unit weight of sediment filtered, actually decreased the food value since filter feeders had to filter more material to obtain nutrients.

\section{Destruction of non-target benthos}

The large, heavy-shelled bivalve Cyprina islandica formed a substantial part of the food of cod and flatfish in Kiel Bay (Baltic) only after trawling began in the area. Arntz \& Weber (1970) concluded that the fish were feeding on bivalves crushed by the otter boards. Medcof \& Caddy (1971) and Caddy (1973) confirmed there was feeding on exposed and damaged benthic animals in trawl tracks. By contrast, observations made using submersibles, reported in Stevens (1990), found that trawling caused no observable injuries to crabs whereas Butcher et al. (1981) found little or no damage to the Jervis Bay (Australia) environment by scallop dredging. These differences in results may well be caused by the different sites used since Creutzberg et al. (1987), for example, found that the number of tickler chains on an experimental beam trawl had no effect on the catches of epibenthic animals over a mud substrate but at sandy stations the number of chains used did correlate to the catch. The effects of trawling can be quite subtle. Bull (1986) found that survival of Pecten novaezelandiae spat in Golden Bay (New Zealand) was better than $20 \%$ after 9 months in an area closed to trawling but was only $0.8 \%$ for an adjacent site which was open to trawling.

Wilson (1979) suggested that patches of the deep water coral Lophelia would be broken up by trawling and thus provide new settlement substrate, increasing the rate of colonisation. However, he also noted that the coral grows at only $6 \mathrm{~mm}$ per year at the depth studied (220-350 m) and that the coral dies when in contact with the substrate. Repeated trawling over the same patch would therefore be expected to eradicate the Lophelia - not spread it. Saxton (1980) and Bradstock \& Gordon (1983) recorded the effects of the systematic destruction by trawlers of the bryozoan beds in Tasman Bay, New Zealand, which provided habitat for juvenile snapper (Pagrus auratus) and tarakihi (Nemadactylus macropterus). The surviving beds were closed to trawling to conserve fish stocks. Riesen \& Reise (1982) describe the removal of Sabellaria reefs in the German Wadden Sea by shrimp fishers clearing trawling grounds of obstacles, and De Groot (1984) makes the point that recolonisation does not occur as the substrate has been changed (though not necessarily by trawlingsee Rees \& Eleftheriou (1989)). Trawling and dredging effects were also implicated in the spread of mussels through the Norderaue area of the Wadden Sea (Reise 1982; Reise \& Schubert 1987).

\section{Dumping of processing waste}

The amounts dumped as "waste" can be substantial. Off India's north-east coast, some 100000 tof bycatch is discarded yearly (Anon. 1991). Wassenberg \& Hill (1990) estimated that Australian prawn trawlers, in catching about $500 \mathrm{t}$ of prawns, discarded $3000 \mathrm{t}$ of material, primarily crustaceans and echinoderms. This dumping can inject high levels of nutrient into the ecosystem providing additional food for birds and predatory fish, but most probably sinks to the seabed causing potential problems with oxygen depletion (Hill \& Wassenberg 1990). By contrast, Berghahn (1990) after noting the rarity of recently discarded fish during bycatch studies in the North Friesian Wadden Sea, estimated that predators (birds, seals, and fish) were capable of clearing discards of moribund fish from the study area. Livingston \& Rutherford (1988) calculated that the discarded waste from the New Zealand West Coast Hoki fishery could be as much as $47800 \mathrm{t}$ dumped in an area of $1000 \mathrm{~km}^{2}$ over 60 days. Rutherford (1987) modelled the potential oxygen depletion such wastes would cause, calculating that oxygen concentrations at the seabed could be reduced to $4-5 \mathrm{~g} \mathrm{~m}^{-3}$ (45-55\% saturation), but actual oxygen measurements have not been made and no studies have been done to establish if discarded material reaches the seabed.

Little published information is available on the effects of discarding fisheries wastes on the seabed 
(Saila 1983) and no studies have been carried out on the compounding effects of exposure of anaerobic sediments by the ploughing effect of the gear. Most published studies have been on shallow water or estuarine sites polluted by onshore processing plants. In coastal waters, small-scale vertical oxygen gradients can be critical (Rosenberg 1977; Jørgensen 1980; Amtz 1981). In the south-east Baltic, Amtz \& Rumohr (1982) recorded a poor benthic fauna in areas of oxygen stress but found that experimental containers of sediment suspended $30-40 \mathrm{~cm}$ above the bottom developed a more normal fauna. Changes to the catch per unit effort in the Norway lobster (Nephrops norvegicus) fishery in the Kattegat have been linked with low oxygen levels bringing the lobsters out of their burrows (Bagge \& Munch-Petersen 1979; Rosenberg 1985). Following complaints from fishers that tailing Nephrops at sea "spoils" the grounds, Chapman (1981) presented evidence that the presence of "heads" appeared to temporarily inhibit Nephrops from emerging from their burrows.

\section{Indirect effects}

McLoughlin et al. (1991) review studies of natural mortality on scallop beds which showed that natural mortality and indirect fishing mortality rates were much higher on fished scallop beds than the natural mortality on unfished beds. They point out that postfishing mortality is not just confined to shells damaged by dredges. Their study showed that 4-5 times as many scallops were crushed or damaged as were caught and landed by the scallop gear used in the Bass Strait (Australia) fishery. However, within 9 months of the start of the fishery "virtually the entire stock was lost", which McLoughlin et al. (1991) attributed to a suspected bacterial infection resulting from decomposing scallops on the seabed.

New Zealand commercial fishers and Ministry of Agriculture and Fisheries staff (including the author) have frequently seen a noticeable reduction in the invertebrate fauna brought up by trawls as new deepwater $(>800 \mathrm{~m})$ grounds are developed. Amounts of non-crustacean invertebrate fauna caught are not recorded, so quantitative evidence is lacking. Saxton (1980) noted a decline in juvenile fish with the removal of bryozoan beds in Tasman Bay, New Zealand. Sainsbury (1988) found a significant reduction in sponge frequency on the Australian north-west shelf between 1967-73 and 1979. Loss of sponges, together with alcyonarians and gorgonians, lead to a change in the catch composition of the pair-trawl fishery on the Australian north-west shelf between those years. The fishes Lethrinus and Lutjanus were associated with habitats containing large epibenthos and catches of these fish species had significantly declined. The fishes Nemipterus and Saurida occurred mostly over the open sand and had increased in biomass.

A general decrease in diversity can be predicted as long-lived slow-growing species are removed or killed by human activities. Reise (1982) noted a disproportionate increase in polychaetes had occurred in the Wadden Sea over the previous 112 years. Pearson et al. (1985) found a $20 \%$ reduction in deposit feeders, a $19 \%$ increase in suspension feeders, and a $25 \%$ increase in predators in the Kattegat between 1911-12 and 1984. Overall, they found an increase in ophiuroids and worms with a decrease in echinoids with the change most apparent in shallow water. Although trawl effects could not be eliminated, these authors suggested that eutrophication was the main cause of the change. Evidence that such changes occur in the absence of trawling was provided by Kröncke (1990) who detected a 30\% decline in the macrofauna total biomass on the northern Dogger Bank between 1950-54 and 1987. Though the drop in biomass was caused by the lack of the bivalve Spisula, the presence of the echinoderm Echinocardium indicated that trawling was unlikely to be the cause. The area of the Dogger Bank in question had not been heavily fished since the 1970s.

\section{THEORETICAL CONSIDERATIONS}

Apart from direct studies on trawl gear, there is a growing body of information on effects to seabed fauna of other potentially disruptive operations (for example, spoil dumping and pollution). Such studies provide information on the resilience of the fauna to stress and particularly on recovery rates. Several studies have focused on the ability of macrofauna to recolonise sediments (summarised in Boesch \& Rosenberg 1981). These studies confirm that recovery rates on the continental shelf and deep sea are much slower than in shallow-water temperate communities (and are measured in years at depths over $1000 \mathrm{~m}$ ). Subsequent work by Flint \& Younk (1983) supports the hypothesis of Boesch \& Rosenberg (1981) that communities in less constant environments are more resistant to disturbance and that colonists in shallow waters are usually species already dominant in the community, rather than short-lived opportunist species. The reverse is true in deeper-water, less disturbed habitats, where colonisers differ markedly from the long-lived equilibrium species. 


\section{SUMMARY AND CONCLUSIONS}

From the work performed under the aegis of ICES, it would appear that beam trawls, otter trawls, and dredges are all basically similar in their effect. Generally, the heavier the gear in contact with the seabed, the greater the damage. The effects vary greatly depending on the amount of gear contact with the bottom, together with the depth, nature of the seabed, and the strength of the currents or tide.

In areas of tide and current, the resuspension of the sediments is of short duration and the effects of the sediment redeposition are not permanent on biota adapted to storm events and sediment transport by currents. However, in areas of little water movement such as in the deep ocean, where the benthos is not adapted to high sediment loads, the adverse effects of sediment resuspension by gear could persist for decades.

The removal of the macrobenthos also has variable effects. In shallow-water areas where the damage is intermittent, recolonisation soon occurs. However, where the macrobenthos is substantially removed and recovery is not permitted (such as the Sabellaria beds of the Wadden Sea and the bryozoan beds of Tasman Bay), the change is permanent.

The predicted changes in shallow-water communities, a relative increase in $r$-strategists such as polychaetes (where population size is determined by the intrinsic rate of population growth $r$ ) and a decrease in $K$-strategists such as molluscs and crustaceans (population size is determined by the carrying capacity of the environment $K$ ), have been observed in the Wadden Sea (Riesen \& Reise 1982), the Kattegat (Pearson et al. 1985), and the English Channel (Holme 1983). There is, however, great difficulty in attributing such observed long-term changes in the benthos to the effects of trawl gear alone, since natural fluctuations and other changes such as chemical dumping and eutrophication have undoubtably occurred (Pearson \& Barnett 1987; Rees \& Eleftheriou 1989).

Most shallow coastal Northern Hemisphere grounds have been fished for centuries and have at the same time been affected by land use changes such as deforestation, pollution, and war. The marine environment was probably changing and adapting before modem "baseline" measurements began (about 100 years ago). The North Sea is not the best place for detecting environmental changes resulting from trawling, but this is where most of the studies have been done.

It is also noticeable in reviewing the literature that authors have underestimated the sampling problems inherent in trying to attribute observed changes to a single cause. Simple pre- versus post-treatment designs, or plot comparison designs (such as that of Graham (1955), do not allow for the separation of effects resulting from the treatment from those effects resulting from other causes (Walters et al. 1988). In addition, many types of impact do not change longrun mean abundances (Underwood 1991). Experimental designs suitable for assessing transient responses to environmental disturbances are becoming available and should be used (Walters et al. 1988; Faith et al. 1991; Underwood 1991).

The evidence is that bottom trawling has an impact on the environment, but that the extent and duration of that impact varies depending on local conditions. There is an urgent need to carry out trawling impact studies in deeper water ( $>500 \mathrm{~m}$ ) since this is where studies indicate that effects could be severe and that any recovery may be measured in decades. Changes to the seabed, by whatever cause (and bottom trawling gear is certainly involved), can affect the fisheries above the beds (Bradstock \& Gordon 1983; Sainsbury 1988). To what extent this is a factor in observed "fishery declines" has seldom been addressed in the literature on fisheries management.

\section{ACKNOWLEDGMENTS}

I am grateful for the helpful comments and encouragement from Peter Horn and Simon Thrush, who commented on an early draft of the manuscript. Two anonymous reviewers made helpful suggestions.

\section{REFERENCES}

Anderson, F. E.; Meyer, L. M. 1986: The interaction of tidal currents on a disturbed intertidal bottom with a resulting change in particulate matter quantity, texture and food quality. Estuarine coastal and shelf science 22: 19-29.

Anonymous 1971: The heavy tickler chain-right or wrong? World fishing, October 1971: 8.

1991: Why stocks of large fish fall. Fishing news international, March 1991: 1-64.

Apollonio, S. 1989: Eliminating otter trawls could be key to better fisheries management. National fisherman, November 1989: 34-35.

Amtz, W. E. 1981: Biomass zonation and dynamics of macrobenthos in an area stressed by oxygen deficiency. In: Barrett, G,; Rosenberg, R. ed. Stress effects on natural ecosystems, pp. 215-225. New York, J. Wiley \& Sons. 
Amtz, W. E.; Rumohr, H. 1982: An experimental study of macrobenthic colonisation and succession, and the importance of seasonal variation in temperate latitudes. Journal of experimental marine biology and ecology 64: 17-45.

Antz, W. E.; Weber, W. 1970: Cyprina islandica L. (Mollusca, Bivalvia) als Nahrung von Dorsch und Kliesche in der Kieler Bucht. Berichte der Deutschen Wissenschaftlichen Kommission für Meeresforschung 21 S: 193-209.

Bagge, O.; Munch-Petersen, S. 1979: Some possible factors governing the catchability of Norway lobster in the Kattegat. Rapports et procès-verbaux des réunions. Conseil international pour l'exploration de la mer 175: 143-146.

Beek F. A. van.; Leeuwen, P. I. van; Rijnsdorp, A. D. 1990: On the survival of plaice and sole discards in the otter-trawl and beam-trawl fisheries in the North Sea. Netherlands journal of sea research 26: 151-160.

Berghahn, R. 1990: On the potential impact of shrimping on trophic relationships in the Wadden Sea. In: Barnes, M.; Gibson, R. N. ed. Trophic relationships in the Marine Ecosystem, pp. 130-140. Proceedings of the 24th European Marine Biology Symposium.

Boesch, D. F.; Rosenberg, R. 1981: Response to stress in marine benthic communities. In: Barrett, G. W.; Rosenberg, R. ed. Stress effects on natural ecosystems, pp. 179-200. New York, J. Wiley \& Sons.

Bradstock, M.; Gordon, D. P. 1983: Coral-like bryozoan growths in Tasman Bay, and their protection to conserve commercial fish stocks. New Zealand journal of marine and freshwater research 17: 159-163.

Bull, M. F. 1986: Scallop enhancement programme approaches first harvesting. Catch 13(3): 10-12.

Butcher, T.; Matthews, J.; Glaister, J.; Hamer, G. 1981: Study suggests scallop dredges causing few problems in Jervis Bay. Australian fisheries 40: 9-12.

Caddy, J. F. 1973: Underwater observations on tracks of dredges and trawls and some effects of dredging on a scallop ground. Journal of the Fisheries Research Board of Canada 30: 173-180.

Caddy, J. F.; Iles, T. D. 1972: Underwater observations on herring spawning grounds on Georges Bank. Research bulletin of the International Commission on Northwest Atlantic Fisheries 10: 13-39.

Chapman, C. J. 1981: Discarding and tailing Nephrops at sea. Scottish fisheries bulletin 46: 10-13.

Chittenden, M. E.; Engel, W. A. van. 1972: Effect of a tickler chain and tow duration on trawl catches of the blue crab, Callinectes sapidus. Transactions of the American Fisheries Society 101: 732-734.
Chong, K. -C.; Dwiponggo, A.; Ilyas, S.; Martosubroto, P. 1987: Some experiences and highlights of the Indonesian trawl ban: Bioeconomics and socioeconomics. Indo-Pacific Fisheries Commission RAPA report 1987(10): 458-477.

Churchill, J. H. 1989: The effect of commercial trawling on sediment resuspension and transport over the Middle Atlantic Bight continental shelf. Continental shelf research 9: 841-864.

Cole, H. A. 1971: The heavy tickler chain-right or wrong?-The view of Dr. H. A. Cole. World fishing, October 1971: 8-10.

Creutzberg, F.; Duineveld, G. C. A.; Noort, G. J. van. 1987: The effect of different numbers of tickler chains on beam-trawl catches. Journal du conseil. Conseil international pour l'exploration de la mer 43: 159-168.

De Groot, S. J. 1984: The impact of bottom trawling on benthic fauna of the North Sea. Ocean management 9: 177-190.

Dolah, R. F. van; Wendt, P. H.; Nicholson, N. 1987: Effects of a research trawl on a hard bottom assemblage of sponges and corals. Fisheries research 5: 39-54.

Faith, D. P.; Humphrey, C. L.; Dostine, P. L. 1991: Statistical power and BACI designs in biological monitoring: Comparative evaluation of measures of community dissimilarity based on benthic macroinvertebrate communities in Rockhole Mine Creek, Northern Territory, Australia. Australian journal of marine and freshwater research 42: 589-602.

Fenaughty, J. M.; Bagley, N. W. 1981: W. J. Scott New Zealand trawling survey: South Island East Coast. New Zealand fisheries technical report 157: 1-224.

Flint, R. W.; Younk, J. A. 1983: Estuarine benthos: longterm community structure variations, Corpus Christi Bay, Texas. Estuaries 6: 126-141.

Galtsoff, P. S. 1964: The American oyster. Fishery bulletin (U.S.) 64: 1-480.

Gibbs, P. J.: Collins, A. J.; Collett, L. C. 1980: Effect of otter prawn trawling on the macrobenthos of a sandy substratum in a New South Wales Estuary. Australian journal of marine and freshwater research 31: 509-516.

Goudey, C. A.; Loverich, G. 1987: Reducing the bottom impact of Alaskan groundfish trawls. Proceedings. Oceans '87. The ocean-an international workplace. 2. Marine engineering, policy education and technology transfer: 632-637.

Graham, M. 1955: Effect of trawling on animals of the sea bed. Deep-sea research 3, supplement: 1-6.

Harden Jones, F. R.; Scholes, P. 1974: The effect of doorto-door tickler chain on the catch-rate of plaice (Pleuronectes platessa L.) taken by an otter trawl. Journal du Conseil. Conseil international pour l'exploration de la mer 35: 210-212. 
Hill B. J.; Wassenberg, T. J. 1990: Fate of discards from prawn trawlers in Torres Strait. Australian journal of marine and freshwater research 41: 53-64.

Holme, N. A. 1983: Fluctuations in the benthos of the westem English Channel. Oceanologica Acta 1983. Proceedings of the 17th European Symposium on Marine Biology, Brest, France, 27 September1 October1982: 121-124.

Hutchings, P. 1990: Review of the effects of trawling on macrobenthic epifaunal communities. Australian journal of marine and freshwater research 41: 111-120.

Jørgensen B. B. 1980: Seasonal oxygen depletion in the bottom waters of a Danish fjord and its effect on the bottom community. Oikos 34: 68-76.

Judd, W. 1989: Deepwater fishing. New Zealand geographic 4: 77-99.

Kröncke, I. 1990: Macrofauna standing stock of the Dogger Bank. A comparison: II. 1951-1952 versus 19851987. Are changes in the community of the northeastem part of the Dogger bank due to environmental changes? Netherlands journal of sea research 25: 189-198.

Krost, P.; Bernhard, M.; Werner, F.; Hukriede, W. 1990: Otter trawl tracks in Kiel Bay (Western Baltic) mapped by side-scan sonar. Meeresforschung 32: 344-353.

Livingston, M.; Rutherford, K. 1988: Hoki wastes on west coast fishing grounds. Catch 15(2): 16-17.

Main, J.; Sangster, G. I. 1979: A study of bottom trawling gear on both sand and hard ground. Scottish fisheries research report 14: 1-15.

1981: A study of the sand clouds produced by trawl boards and their possible effect on fish capture. Scottish fisheries research report 20: 1-20.

March, E. J. 1970: Sailing trawlers: The story of fishing with longline and trawl. London, David and Charles.

Mayer, L. M.; Schick, D. F., Findlay, R. H.; Rice, D. L. 1991: Effects of commercial dragging on sedimentary organic matter. Marine environmental research 31: 249-261.

McAllister, D. 1991: Questions about the impact of trawling. Sea wind 5(2): 28-33.

McLoughlin R. J.; Young, P. C.; Martin, R. B.; Parslow, J. 1991: The Australian scallop dredge: estimates of catching efficiency and associated indirect fishing mortality. Fisheries research 11:1-24.

Medcof, J. C.; Caddy, J. F. 1971: Underwater observations on performance of clam dredges of three types. ICES gear behaviour committee document 1971I B10: $1-7$.

Meyer, T. L.; Cooper, R. A.; Pecci, K. J. 1981: The performance and environmental effects of a hydraulic clam dredge. Marine fisheries review 43: 14-22.
Pearson, T. H.; Barnett, P. R. O. 1987: Long-term changes in benthic populations in some west European coastal areas. Estuaries 10: 220-226.

Pearson, T. H.; Josefson, A. B.; Rosenberg, R. 1985: Petersen's benthic stations revisited. I. Is the Kattegatt becoming eutrophic? Journal of experimental marine biology and ecology 92: 157-206.

Redant, F. 1987: A bibliography on the effects of bottom fishing gear and harvesting techniques on benthic biota. Annex to 6th report of the benthos ecology working group, ICES CM 1987/L 26: 1-8.

1990: An updated bibliography on the effects of bottom fishing gear and harvesting techniques on seabed and benthic biota. Working document to the study group on ecosystem effects of fishing activities. International Council for the Exploration of the Sea. $12 \mathrm{p}$.

Rees, H. L.; Eleftheriou, A. 1989: North Sea benthos: A review of field investigations into the biological effect of man's activities. Journal du Conseil. Conseil international pour l' exploration de la mer 45: 284-305.

Reise, K. 1982: Long-term changes in the macrobenthic invertebrate fauna of the Wadden Sea: Are polychaetes about to take over? Netherlands journal of sea research 16: 29-36.

Reise, K.; Schubert, A. 1987: Macrobenthic turnover in the subtidal Wadden Sea: the Norderaue revisited after 60 years. Helgolander Meeresuntersuchungen 41: 69-82.

Riesen, W.; Reise, K. 1982: Macrobenthos of the subtidal Wadden Sea: revisited after 55 years. Helgolander Meeresuntersuchungen 35: 409-423.

Rijnsdorp, A. D.; Groot, P.; Beek, F.A. van 1991: The micro distribution of beam trawl effort in the southern North Sea. ICES Demersal fish committeel Session P. document 1991/G49: 1-20.

Rosenberg, R. 1977: Benthic macrofaunal dynamics, production, and dispersion in an oxygen-deficient estuary of West Sweden. Journal of experimental marine biology and ecology 26: 107-133.

1985: Eutrophication-the future marine coastal nuisance? Marine pollution bulletin 16(6): 227-231.

Rutherford, J. C. 1987: A preliminary study of the dispersion of hoki wastes and potential oxygen depletion off the West Coast South Island. Fisheries Research Centre internal report 79. (Draft report held in Fisheries Research Centre library, Wellington.) $42 \mathrm{p}$.

Saila, S. B. 1983: Importance and assessment of discards in commercial fisheries. FAO Fisheries circular $765.62 \mathrm{p}$. 
Sainsbury, K. J. 1988: The ecological basis of multispecies fisheries and management of a demersal fishery in tropical Australia. In: Gulland, J. A. ed. Fish population dynamics (2nd edn.), pp. 349-382. London, J. Wiley \& Sons.

Saxton, F. 1980: Coral loss could deplete fish stocks. Catch 7(8): 12-13.

Stevens, B. G. 1990: Survival of king and tanner crabs captured by commercial sole trawls. Fishery bulletin (US.) 88: 731-744.

Stevens, P. M. 1987: Response of excised gill tissue from the New Zealand scallop Pecten novaezelandiae to suspended silt. New Zealand journal of marine and freshwater research 21: 605-614.

Theil, H.; Schriever, G. 1990: Deep-sea mining, environmental impact and the DISCOL project. AMBIO 19: 245-250.

Underwood, A.J. 1991: Beyond BACI: Experimental designs for detecting human environmental impacts on temporal variations in natural populations.
Australian journal of marine and freshwater research 42: 569-587.

Walters, C. J.; Collie, J. S.; Webb, T. 1988: Experimental designs for estimating transient responses to management disturbances. Canadian journal of fisheries and aquatic sciences 45: 530-538.

Wassenberg, T. J.; Hill, B. J. 1990: Partitioning of material discarded from prawn trawlers in Moreton Bay. Australian journal of marine and freshwater research 41: 27-36.

Wenner, C. A. 1983: Species associations and day-night variability of trawl-caught fishes from the inshore sponge-coral habitat, South Atlantic bight. Fishery bulletin (US.) 81: 537-552.

Wilson, J. B. 1979: 'Patch' development of the deepwater coral Lophelia pertusa (L.) on Rockall Bank. Journal of the Marine Biological Association of the United Kingdom 59: 165-177.

Yamamoto, G. 1960: Mortalities of the scallop during its life cycle. Bulletin of the Marine Biological Station at Asamushi 10: 149-152. 